\title{
Hubungan Riwayat ASI Eksklusif dengan Kejadian Stunting pada Anak Usia 12-59 Bulan di RSUD Wangaya Kota Denpasar
}

\author{
Cynthia $^{1}$, I Wayan Bikin Suryawan ${ }^{2}$, A.A Made Widiasa ${ }^{2}$ \\ ${ }^{1}$ Fakultas Kedokteran dan Ilmu Kesehatan Universitas Kristen Krida Wacana \\ ${ }^{2}$ Departemen Ilmu Kesehatan Anak Rumah Sakit Umum Daerah Wangaya Kota Denpasar
}

\begin{abstract}
Abstrak
Stunting masih menjadi masalah kesehatan dan Indonesia. Stunting terjadi akibat kekurangan gizi kronis sehingga tinggi badan atau panjang badan anak tidak mencapai sesuai usianya dengan skor z <2 deviasi standar menurut standar Badan Kesehatan Dunia (WHO). Gangguan pertumbuhan sering terjadi mulai dari masa kehamilan hingga usia anak mencapai dua tahun. Pemenuhan nutrisi selama 1000 hari pertama kehidupan sangatlah penting untuk masa depan. Salah satu faktor yang menyebabkan stunting adalah kurangnya asupan gizi yang baik, termasuk bila bayi baru lahir tidak mendapat Air Susu Ibu (ASI) eksklusif. Tujuan penelitian ini untuk mengetahui hubungan antara riwayat pemberian ASI eksklusif dengan kejadian stunting. Penelitian ini adalah penelitian studi observasional analitik dengan metode potong lintang menggunakan data sekunder dari rekam medis. Sampel pada penelitian ini adalah anak berusia 12-59 bulan yang dirawat di Ruang Kaswari RSUD Wangaya. Sebanyak 64 sampel didapatkan dari Januari hingga April 2018 dengan metode sampling konsekutif. Hasil penelitian menunjukan bahwa 25 anak $(39,1 \%)$ mengalami stunting. Riwayat pemberian ASI ekslusif terdapat pada 27 anak $(42,2 \%)$. Hasil analisis menunjukkan nilai p sebesar 0,604 dengan rasio prevalensi 1,265. Secara statistik tidak terdapat hubungan signifikan antara ASI eksklusif dan stunting pada anak usia 1259 bulan di RSUD Wangaya Kota Denpasar.
\end{abstract}

Kata Kunci: ASI eksklusif, stunting, 1000 hari pertama kehidupan

\section{The Association Between Exclusive Breastfeeding and Stunting in Children Age 12-59 Months at Wangaya Hospital Denpasar}

\begin{abstract}
Stunting is still a public health problem and Indonesia. - Children are categorized as stunted if their height or length for age is two standard deviations below the World Health Organization (WHO) Child Growth Standard. Growth faltering is often begins from pregnancy until the child is two years old. The fulfillment of nutrition in the first 1000 day of childhood is very crucial. One of the risk factors of stunting is insufficient nutrient intake, such as lack of exclusive breastfeeding after birth. The aim of research is to investigate the correlation between exclusive breastfeeding and stuntingin. The research is an analytical observational study with a cross-sectional design using secondary data from the medical record. Samples were children age 12-59 months who were admitted to Wangaya Hospital Denpasar. Sixty four medical records from January 2018 until April 2018 were obtained using consecutive sampling. The results showed 25 children (39.1\%) with stunting and 39 children (60.9\%) were not stunted. There were 27 children (42.2\%) with history of exclusive breastfeeding whereas 37 children (57.8\%) who did not receive exclusive breastfeeding. A p value of 0.604 was obtained with a prevalence ratio of 1,265 , which indicate that there is no significant relationship between exclusive breastfeeding and stunting in children aged 12-59 months at Wangaya Hospital, Denpasar City.
\end{abstract}

Keywords: exclusive breastfeeding, stunting, the first 1000 days 


\section{Pendahuluan}

Stunting adalah kondisi gagal tumbuh pada anak bawah lima tahun (balita) akibat kekurangan gizi kronis, yang ditandai tinggi badan anak yang tidak sesuai dengan usianya. Kekurangan gizi terjadi sejak bayi dalam kandungan dan pada masa awal setelah bayi lahir. ${ }^{1}$ Karena itu, penanggulangan balita stunting yang paling efektif dilakukan pada 1.000 Hari Pertama Kehidupan (HPK) yang meliputi 270 hari selama kehamilan dan 730 hari pertama setelah bayi yang dilahirkan. Akan tetapi, kondisi stunting ini baru nampak setelah bayi berusia dua tahun. ${ }^{2-3}$

Indonesia menduduki peringkat kelima dunia untuk jumlah anak dengan kondisi stunting. ${ }^{3-4}$ Lebih dari sepertiga anak berusia di bawah lima tahun di Indonesia tingginya berada di bawah rata-rata ${ }^{3}$ Diperkirakan terdapat 162 juta balita pendek pada tahun 2012 dan jika berlanjut tanpa upaya penurunan, diproyeksikan akan menjadi 127 juta pada tahun 2025. ${ }^{2,4}$ Sebanyak $56 \%$ anak pendek ditemukan di Asia dan 36\% di Afrika. ${ }^{2}$

Riset Kesehatan Dasar 2013 mencatat prevalensi stunting nasional mencapai 37,2 persen, meningkat dari tahun $2010(35,6 \%)$ dan 2007 (36,8\%). ${ }^{2}$ Prevalensi masalah stunting pada balita secara nasional masih tinggi, namun di provinsi Bali sebesar 20,6\%, lebih rendah dari angka Nasional. ${ }^{5}$ Menurut WHO, prevalensi balita stunting menjadi masalah kesehatan masyarakat jika prevalensi stunting $20 \%$ atau lebih. $^{2}$

Beberapa faktor yang menjadi penyebab stunting adalah gizi ibu atau calon ibu, pola asuh, pengetahuan ibu dan ayah, Berat Badan Lahir rendah (BBLR), riwayat ASI eksklusif, imunisasi, terbatasnya pelayanan kesehatan termasuk layanan Ante Natal Care (ANC) dan post natal care, kondisi sanitasi dan akses air minum, kurangnya akses rumah tangga/keluarga ke makanan bergizi, serta pendapatan keluarga. ${ }^{1,2,4}$

Dampak buruk yang dapat ditimbulkan dalam jangka pendek adalah terganggunya perkembangan otak, kecerdasan, gangguan pertumbuhan fisik, dan gangguan metabolisme dalam tubuh. ${ }^{2,6}$ Sedangkan dalam jangka panjang akibat buruk yang dapat ditimbulkan adalah menurunnya kemampuan kognitif dan prestasi belajar, menurunnya kekebalan tubuh sehingga mudah sakit, dan risiko tinggi untuk munculnya penyakit diabetes, kegemukan, penyakit jantung dan pembuluh darah, kanker, stroke, dan disabilitas pada usia tua, serta kualitas kerja yang tidak kompetitif yang berakibat pada rendahnya produktivitas ekonomi. $^{2}$

United Nation Children Fund (UNICEF) dan World Health Organization (WHO) merekomendasikan ASI selama paling sedikit 6 bulan. $^{7}$ Berdasarkan Peraturan Pemerintah Nomor 33 Tahun 2012, ASI eksklusif adalah ASI yang diberikan kepada bayi sejak dilahirkan selama enam bulan, tanpa menambahkan dan/atau mengganti dengan makanan atau minuman lain (kecuali obat, vitamin dan mineral). ${ }^{2}$ Pada bayi, Air Susu Ibu (ASI) sangat berperan dalam pemenuhan nutrisinya. ${ }^{8}$ Konsumsi ASI juga meningkatkan kekebalan tubuh bayi sehingga menurunkan risiko penyakit infeksi. ${ }^{8}$ Kadar mineral pada ASI tidak dipengaruhi oleh makanan yang dikonsumsi ibu dan status nutrisi ibu. Mineral dalam ASI lebih mudah diserap di banding mineral dalam susu sapi. Mineral utama yang terdapat pada ASI adalah kalsium yang berfungsi untuk pertumbuhan jaringan otot dan rangka, transimi jaringan saraf dan pembekuan darah. ${ }^{9}$ Walaupun kadar kalsium lebih rendah dibandingkan susu sapi namun tingkat penyerapannya lebih tinggi. ${ }^{9}$ Penyerapan kalsium ini dipengaruhi kadar fosfor, magnesium, vitamin $\mathrm{D}$, dan lemak. ${ }^{9}$ Hal inilah yang mendukung pertumbuhan bayi terutama tinggi badan sehingga bayi yang diberikan ASI juga memiliki tinggi badan yang lebih tinggi dan sesuai dengan kurva pertumbuhan dibandingkan dengan bayi yang diberikan dengan susu formula. Dengan pemberian ASI, bayi dapat terhindar dari resiko stunting. ${ }^{10}$

Pencapaian ASI eksklusif di Indonesia belum dapat mencapai angka yang diharapkan yaitu sebesar $80 \% .^{2}$ Tahun 2012 , pencapaian ASI eksklusif adalah $42 \% .^{2}$ Sedangkan, berdasarkan laporan dari Dinas Kesehatan Provinsi tahun 2013, cakupan pemberian ASI 06 bulan hanyalah 54,3\%. ${ }^{2}$ Pada tahun 2015 di Indonesia hanya sebesar $41,9 \%{ }^{2}$ Tiga provinsi dengan capaian tertinggi adalah Nusa Tenggara Barat (78,9\%), Jawa Timur $(65 \%)$ dan Lampung $(57,3 \%)$ sedangkan tiga provinsi terendah adalah Kalimantan Tengah $(15,8 \%)$, Sumatera Utara $(20,3 \%)$ dan DKI Jakarta (20,3\%), sedangkan Papua data belum tersedia. ${ }^{1-2}$ Data WHO tahun 2016 masih menunjukkan rata-rata angka pemberian ASI eksklusif di dunia baru berkisar 38\%. ${ }^{5}$

Menurut penelitian Damiyanti pada tahun 2016 menyatakan bahwa ada hubungan ASI 
eksklusif dengan kejadian stunting pada anak balita. ${ }^{11} \mathrm{Hal}$ ini berbeda dengan penelitian yang dilakukan oleh Marlan dkk. pada tahun 2017, yang menyatakan bahwa tidak adanya hubungan antara pemberian ASI eksklusif dengan kejadian stunting pada anak balita di wilayah kerja Puskesmas Sonder. ${ }^{12}$ Berdasarkan latar belakang masalah di atas, maka penelitian ini bertujuan untuk mengetahui hubungan antara riwayat ASI eksklusif dengan kejadian stunting pada anak usia 12 -59 bulan.

\section{Metode Penelitian}

Penelitian ini merupakan penelitian analitik observasional dengan desain potong lintang.Variabel bebas dalam penelitian ini adalah riwayat ASI eksklusif dan yang merupakan variabel tergantung (efek) adalah kejadian stunting. Populasi terjangkau adalah semua anak yang mengalami stunting berusia 12-59 bulan yang dirawat di ruang Kaswari RSUD Wangaya Kota Denpasar periode Januari-April 2018.

Sumber data dalam penelitian ini adalah berupa data sekunder yang berasal dari rekam medis pasien. Persetujuan penelitian dan penggunaan rekam medis telah disetujui oleh Kepala bagian SMF Anak di RSUD Wangaya Denpasar. Enam puluh empat sampel dikumpulkan dengan menggunakan teknik konsekutif. Data yang dikumpulkan adalah jenis kelamin, umur, berat badan lahir, berat badan sekarang, riwayat ASI eksklusif, status gizi, dan penyakit infeksi yang sedang diderita saat dirawat di ruang Kaswari.

Pengukuran panjang badan dan berat badan dilakukan pada anak usia kurang dari 24 bulan dengan menggunakan alat ukur panjang badan bayi atau infantometer dan timbangan bayi. Untuk anak usia lebih dari 24 bulan menggunakan alat Microtoise (stature meter) dan timbangan berdiri. Penentuan status gizi dengan menggunakan kurva berat badan terhadap panjang badan atau tinggi badan anak usia 0-5 tahun sesuai dengan standar baku WHO- Multicentre Growth Reference Study (WHO-MGRS) 2006. Anak balita dengan skor $\mathrm{z}<-2$ Standard Deviation (SD) sampai -3 SD ( gizi kurang), -2 SD sampai +2 SD ( gizi baik) dan > +2 SD sampai +3 SD ( gizi lebih).Penentuan stunting dilakukan dengan menggunakan standar baku WHO-MGRS 2006 dan menurut Kementerian Kesehatan (Kemenkes) adalah anak balita dengan skor $\mathrm{z}$ kurang dari -2 SD (stunted) dan kurang dari 3SD (severely stunted).

Data yang telah dikumpulkan kemudian diolah dengan menggunakan Statistical Product and Service Solution (SPSS) 23.0 untuk Windows dan disajikan dalam bentuk diagram dan tabel. Analisis univariat untuk mendeskripsikan karakteristik responden dalam penelitian. Data usia dilampirkan dalam bentuk rerata dan untuk mengetahui sebaran data numerik seperti umur menggunakan parameter Kolmogorov-Smirnov dengan kriteria sebaran normal > 0,05 dan untuk mengetahui sebaran data kategorik seperti jenis kelamin dengan menghitung rasio skewness dengan kriteria normal -2 sampai dengan 2 SD.Analisis bivariat untuk mencari hubungan ASI eksklusif dengan kejadian stunting di ruang Kaswari RSUD Wangaya Denpasar dengan menggunakan uji statistik Chi Square. .

\section{Hasil Penelitian}

Selama periode penelitian, setelah memenuhi kriteria inklusi dan eksklusi 64 anak dijadikan sebagai sampel. Didapatkan 39 anak yang tidak mengalami stunting dan 25 anak yang mengalami stunting. Berikut disajikan diagram sampel berdasarkan karakteristik jenis kelamin, umur, berat badan lahir, riwayat ASI eksklusif, status gizi, dan infeksi.

\section{Karakteristik Sampel Penelitian}

Pada Gambar 1 dan 2, hasil rasio skewness sebesar 0,645 yang menunjukkan persebaran sampel menurut jenis kelamin cukup merata, dimana laki-laki lebih banyak dari perempuan sebesar 54,7\%. Untuk kategori usia, hasil Kolmogrov-Smirnov menunjukkan nilai p 0,000 di mana usia tidak berdistribusi normal dengan usia dominan $12-24$ bulan dan tinggi badan balita berkisar 73,28- 93,58 cm.

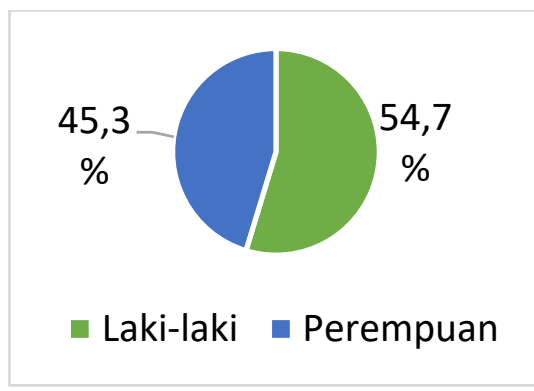

Gambar 1. Karateristik Sampel Berdasarkan Jenis Kelamin 
Seperti yang ditampilkan pada Gambar 3 dan 4, anak yang mengalami stunting sebesar 39,1\% dan yang tidak mengalami stunting $60,9 \%$.

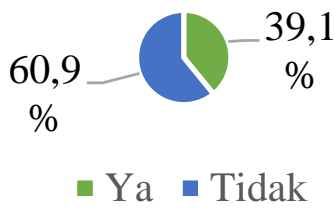

Gambar 3. Gambar Karakteristik Sampel Berdasarkan Stunting
Anak yang dirawat di ruang Kaswari masih lebih banyak memiliki riwayat tidak mendapat ASI eksklusif (57,8\%).

Pada Gambar 5 dan 6, Kelompok anak yang dirawat lebih banyak dengan gizi baik sebesar $62,5 \%$ dengan berat badan lahir $\geq 2500 \mathrm{~g}$ sebanyak 92,20\%. Gambar 7 menunjukkan bahwa anak-anak yang dirawat di ruang kaswari Januari-April 2018 lebih banyak menderita sakit Infeksi Saluran Pernapasan Atas (ISPA) sebanyak $56,3 \%$.

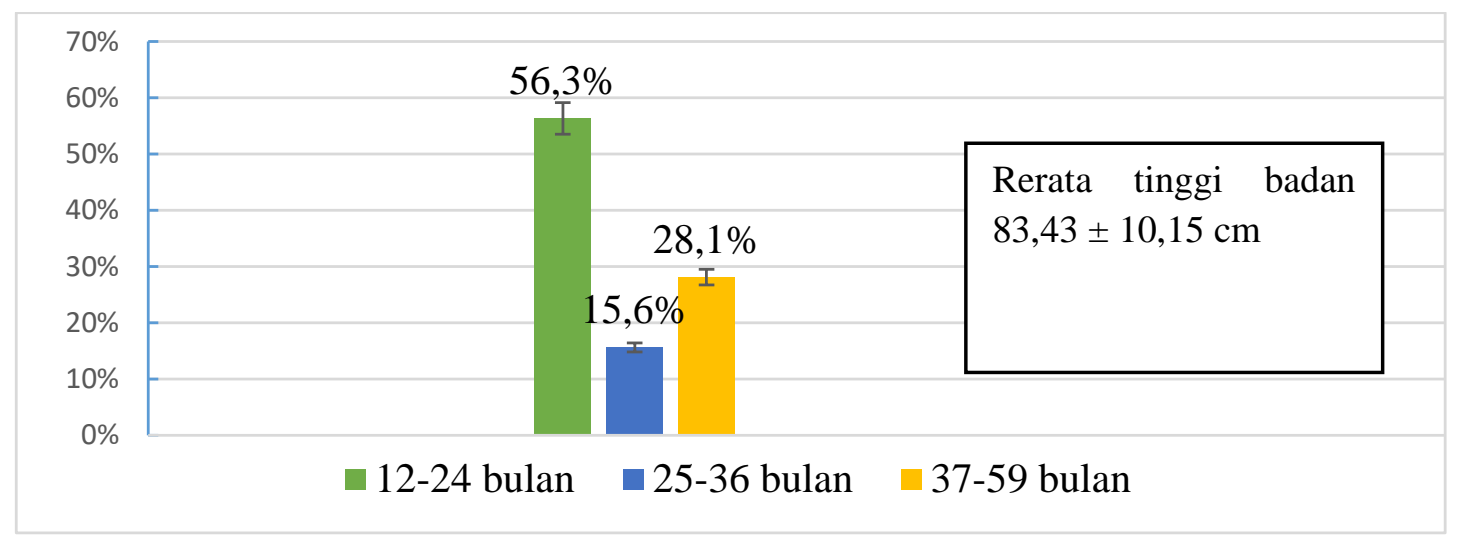

Gambar 2. Karakterisik Sampel Berdasarkan Usia dan Tinggi Badan

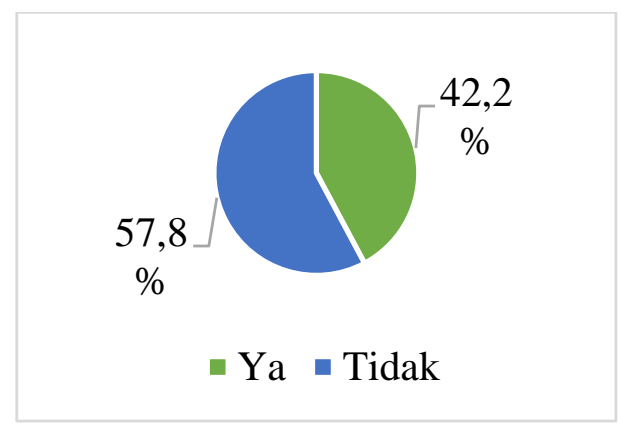

Gambar 4. Karakteristik Responden Berdasarkan Pemberian ASI Eksklusif

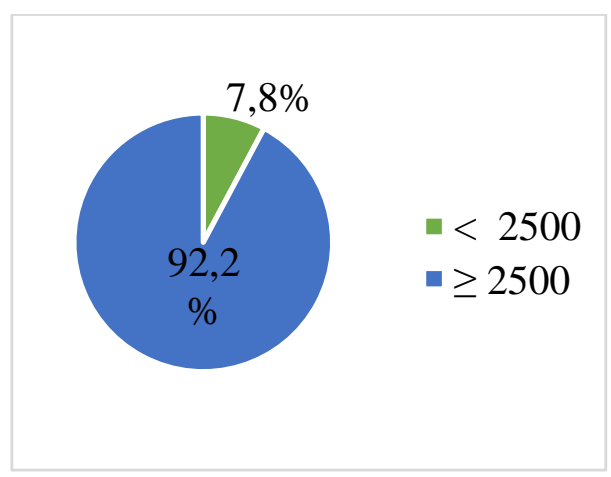

Gambar 6 .Karakteristik Sampel Berdasarkan Berat Badan Lahir

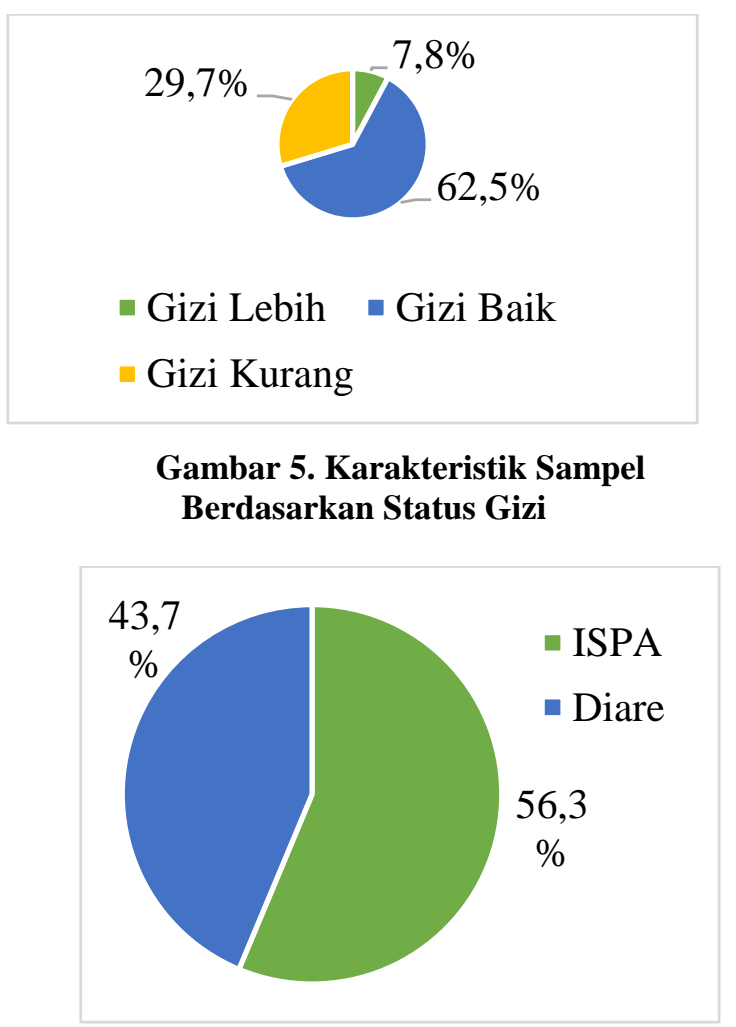

Gambar 7. Karakteristik Sampel Berdasarkan Infeksi 
Tabel 1. Jumlah Anak yang Mengalami Stunting dengan Riwayat Pemberian ASI dan Tidak

\begin{tabular}{|c|c|c|c|c|c|}
\hline \multirow{2}{*}{ Variabel } & \multicolumn{2}{|c|}{ Stunting } & \multirow[t]{2}{*}{ Total } & \multirow[t]{2}{*}{ RP (IK 95\%) } & \multirow[t]{2}{*}{$\mathbf{P}$} \\
\hline & Ya & Tidak & & & \\
\hline \multicolumn{6}{|l|}{$\begin{array}{l}\text { ASI eksklusif } \\
\text { Ya }\end{array}$} \\
\hline \multirow{2}{*}{ Tidak } & & & & $\begin{array}{c}1,265 \\
(0,689-2,323)\end{array}$ & 0,604 \\
\hline & $13(20,3 \%)$ & $24(37,5 \%)$ & $37(57,8 \%)$ & & \\
\hline Total & $25(39,1 \%)$ & $39(60,9 \%)$ & $64(100 \%)$ & & \\
\hline
\end{tabular}

Pada Tabel 1, didapatkan jumlah anak yang mengalami stunting dengan riwayat pemberian ASI eksklusif sebanyak 12 orang $(18,8 \%)$ sedangkan yang tidak mendapat ASI eksklusif sebesar 13 orang $(20,3 \%)$. Hasil uji hipotesis dalam penelitian ini menggunakan uji chi square dengan nilai $\mathrm{p}$ sebesar 0,604. Karena nilai $\mathrm{p}>0,05$, maka dapat disimpulkan bahwa tidak terdapat hubungan yang signifikan antara ASI eksklusif dengan kejadian stunting pada anak usia $12-59$ bulan.

\section{Pembahasan}

Pada penelitian ini karakteristik sampel yang digunakan adalah jenis kelamin, umur, berat badan lahir, berat badan, tinggi badan, riwayat ASI eksklusif, status gizi dan infeksi. Keseluruhan sampel berjumlah 64 orang dimana yang mengalami stunting sebanyak 25 orang dan 39 orang yang tidak mengalami stunting.

Usia terbanyak pada penelitian ini adalah 12-24 bulan. Periode percepatan tumbuh kembang dimulai sejak terbentuknya janin dalam kandungan hingga anak berusia dua tahun. ${ }^{13}$ Pada masa ini terjadi pertumbuhan otak yang sangat pesat dan pertumbuhan anak dimana nutrisi yang diterima oleh bayi saat dalam kandungan dan menerima ASI, memiliki dampak jangka panjang terhadap kehidupan saat usia dewasa. ${ }^{14}$ Pertumbuhan bayi pada periode emas 0-24 bulan, masih bisa diperbaiki. ${ }^{14}$ Tetapi bila gangguan pertumbuhan berlanjut sampai anak usia 2 tahun dan tidak mendapatkan terapi, maka kondisi ini tidak dapat di koreksi. ${ }^{13-14}$

Laki-laki $54,70 \%$ lebih banyak dibandingkan dengan perempuan sebesar $45,30 \%$. Pada penelitian yang dilakukan oleh
Wamani H dkk (2007) di Sub-Sahara Afrika menunjukkan anak laki-laki di bawah 5 tahun lebih cenderung dapat mengalami stunting dari pada anak perempuan. ${ }^{15}$ Penelitian Damiyanti (2016) juga menunjukkan bahwa anak laki-laki memiliki risiko lebih tinggi mengalami stunting dibandingkan perempuan karena lebih berisiko untuk mengalami kekurangan gizi akibat lebih banyaknya kebutuhan energi protein pada lakilaki. ${ }^{11}$ Tinggi badan rerata balita baik laki-laki maupun perempuan yang dirawat di Ruang Kaswari adalah $83,43 \pm 10,15 \mathrm{~cm}$.

Berat badan lahir lahir $\geq 2500 \mathrm{~g}$ dalam penelitian ini lebih banyak 92,2\% dibandingkan dengan berat badan lahir $<2500 \mathrm{~g}$ sebesar $7,8 \%$. Balita dengan berat badan lahir rendah (BBLR) cenderung memiliki risiko untuk menjadi stunting karena memiliki kerentanan yang lebih tinggi terhadap penyakit infeksi dan hilangnya nafsu makan. ${ }^{16-17}$

Anak yang dirawat di Ruang Kaswari lebih banyak dengan status gizi yang baik sebesar $62,5 \%$ dibandingkan dengan gizi kurang 29,7\% dan gizi buruk $7,8 \%$. Usia 2-5 tahun merupakan usia rawan terjadinya kurang gizi karena pada usia ini ASI sudah tidak diberikan sehingga zat gizi yang diterima oleh balita hanya berasal dari diet saja. ${ }^{11}$ Pada usia ini, balita sudah mampu memilih makanan sendiri. Balita yang mengalami kekurangan gizi sebelumnya masih dapat diperbaiki denganm asupan yang baik sehingga dapat melakukan tumbuh kejar sesuai dengan perkembangannya. ${ }^{11}$ Namun, apabila intervensinya terlambat, balita tidak akan dapat mengejar keterlambatan pertumbuhannya yang disebut dengan gagal tumbuh. Begitu pula dengan balita yang normal kemungkinan terjadi gangguan pertumbuhan bila asupan yang diterima tidak mencukupi. ${ }^{11}$ 
Penyakit infeksi merupakan faktor langsung terjadinya masalah gizi. ${ }^{18}$ Seorang anak yang mengalami stunting lebih memiliki kemungkinan yang lebih besar untuk menderita penyakit infeksi dengan durasi yang lebih lama. ${ }^{19}$ Jenis penyakit infeksi yang terbanyak dialami responden adalah ISPA sebesar 56,3\%. ISPA masih merupakan salah satu masalah kesehatan masyarakat yang besar, terutama pada balita. Selain ISPA, jenis penyakit yang jumlahnya cukup tinggi pada anak adalah diare. ${ }^{18-19}$

Pola asuh ibu terhadap anaknya juga merupakan salah satu faktor yang dapat mempengaruhi status gizi balita. Pola asuh dalam penelitian ini berhubungan dengan pemberian ASI eksklusif. ${ }^{20-21}$ Pada penelitian dapat disimpulkan bahwa masih banyak balita yang tidak mendapatkan ASI eksklusif $(57,8 \%)$. Menurut catatan rekam medis pada bagian anamnesis, diketahui banyak ibu balita yang memberikan ASI dikombinasikan dengan susu formula. Alasan yang paling banyak dikemukakan oleh ibu adalah ASI tidak lancar, selain itu ibu bekerja dan bayi masih rewel meskipun sudah diberi ASI. ${ }^{22}$ Mudahnya mendapatkan susu formula membuat ibu kurang berusaha untuk meningkatkan produksi ASI. ${ }^{22}$ Menyusui sekaligus memberikan susu formula memang dapat memenuhi kebutuhan zat gizi bayi sehingga tidak terganggu pertumbuhannya, tetapi susu formula tidak mengandung zat antibodi sebaik ASI sehingga bayi lebih rawan terkena penyakit. ${ }^{22}$

Dari 64 responden didapatkan 25 balita yang mengalami stunting. Hasil analisa pada penelitian ini yang menghubungkan antara ASI eksklusif dengan kejadian stunting dan didapatkan nilai $p$ sebesar 0,604 ( $p>0,05)$. Hal ini berarti ASI eksklusif tidak memiliki hubungan yang bermakna dengan kejadian stunting pada bayi usia 12-59 bulan.

Hasil analisis ini bertentangan dengan penelitian yang dilakukan oleh Astria,dkk pada tahun 2015 yang menunjukkan bahwa terdapat hubungan bermakna antara pemberian ASI eksklusif dengan kejadian stunting dengan nilai p 0,0001 dengan rasio prevalensi 1,19.23 Menurut penelitian yang dilakukan oleh Damayanti pada tahun 2016 juga menunjukan adanya hubungan bermakna antara pemberian ASI eksklusif dengan balita stunting dengan nilai $\mathrm{p}=0,001 .{ }^{11}$ Balita dengan riwayat mendapatkan ASI tidak eksklusif memiliki risiko stunting 16,5 kali lebih besar dibandingkan balita dengan riwayat mendapatkan ASI eksklusif. ${ }^{11}$ Adanya perbedaan hasil pada penelitian ini disebabkan karena ASI eksklusif bukanlah satu-satunya penyebab stunting, tetapi dapat juga disebabkan oleh faktor lainnya seperti asupan makanan diluar ASI karena kebutuhan zat gizi tinggi, khususnya setelah masa pemberian ASI eksklusif dan penyakit infeksi. ${ }^{23-25}$

\section{Simpulan}

Dari hasil penelitian tersebut dapat disimpulkan bahwa tidak didapatkan hubungan yang signifikan antara riwayat ASI eksklusif dengan kejadian stunting pada anak usia 12-59 bulan di RSUD Wangaya Kota Denpasar.

\section{Daftar Pustaka}

1. Tim Nasional Percepatan penanggulan kemiskinan kabupaten atau kota prioritas untuk intervensi anak kerdil (stunting). 2017. [diunduh 12 Feb 2018]. Tersedia dari: https://www.tnp2k.go.id

2. Pusat Data dan Informasi Kementerian Kesehatan RI. Situasi balita pendek dan ASI eksklusif. 2016. [diunduh $12 \mathrm{Feb}$ 2018]. Tersedia dari: https://www.depkes.co.id

3. Millenium Challange Account-Indonesia. Stunting dan masa depan Indonesia. 2013. [diunduh 12 Feb 2018]. Tersedia dari: https://www.mcaindonesia.go.id/assets/uploads/media/pdf/ MCAIndonesia-Technical-Brief-StuntingID.pdf

4. Trihono, Atmarita, Tjandrarini DH, Irawati A, Urami NH, Tejayanti $\mathrm{T}$, et al. Pendek (stunting) di Indonesia: masalah dan solusinya. Jakarta: Lembaga Penerbit Balitbangkes; 2015.

5. Departemen Kesehatan Bali. Data dan informasi kesehatan provinsi Bali. 2015. [diunduh 14 Feb 2018]. Tersedia dari: www.diskes.baliprov.go.id

6. UNICEF. Levels and trends in child malnutrition. 2015. [diunduh $12 \mathrm{Feb}$ 2018]. Tersedia dari: www.unicef.org

7. Kementrian Kesehatan RI. Situasi dan analisis ASI eksklusif. 2017. [diunduh 13 Feb 2018]. Tersedia dari: www.deples.go.id

8. Rivanaica R, Oxyandi M. Buku ajar deteksi dini tumbuh kembang dan 
pemeriksaan bayi baru lahir. Jakarta: Salemba Medika, 2016.

9. Hendarto A, Pringgadini K. Nilai nutrisi air susu ibu. [diunduh 14 Feb 2018]. Tersedia dari: www.idai.or.id

10. Roche ML, Gyorkos TW, Blouin B, Marquis GS, Sarsoza J, Kuhnlein H. Infant and young child feeding practice and stunting in two highland provinces in Ecuador. Matern child Nutr. 2016;13(2):115.

11. Damayanti RA, Muniroh L, Farapti. Perbedaan tingkat kecukupan zat gizi dan riwayat pemberian asi eksklusif pada balita stunting dan non stunting. Media Gizi Indonesia. 016;11(1):61-9.

12. Pangkong M, Rattu A.J.Malonda Nancy S.H. Hubungan antara pemberian ASI eksklusif dengan kejadian stunting pada anak usia 13-26 bulan di wilayah kerja Puskesmas Sonder.Artikel Penelitian.Manado : Universitas Sam Ratulangi Manado; 2017.

13. Prentice AM, Ward KA, Goldberg GR, Jarjou LM, Moore SE, Fulford AJ, et al. Critical windows for nutritional interventions against stunting. Am J Clin Nutr. 2013;65(5):911-8.

14. Kathryn D. Reducing stunting by improving maternal, infant, and young child nutrition ini regions such as South Asia: evidence, challence and opportunities. Maternal and Child Nutrition. 2016;12(1):27-38.

15. Wamani H, Astrom An, Peterson, Tumwine, Tylleskar. Boys are more stunted than girls in sub saharan Africa: a meta-analysis of 16 demographic and health surveys. BMC pediatr. 2007;7:7-17.

16. Pudjiadi AH, Hegar B, Handryastuti S, Idris NS, Gandaputra EP, Harmoniati ED. Buku pedoman pelayanan medis IDAI. Jilid 1. Jakarta: IDAI; 2010:23-7.

17. Nasution N, Nurdiati DS, Huriyat E. Hubungan berat badan lahir rendah dengan kejadian stunting pada anak usia 6-24 bulan di kota Yogyakarta. Jurnal Gizi Klinik Indonesia. 2014;11(1):31-7.

18. Aulia D. Determinan stunting pada anak usia 24-59 bulan di Kelurahan Cimahpar Bogor Utara. Bogor: Departemen Gizi Masyarakat Fakultas Ekologi Manusia Institut Pertanian Bogor; 2016. Artikel Penelitian.

19. Kusumawati E, Rahardjo S, Sari HP. Model pengendalian faktor risiko stunting pada anak usia di bawah 3 tahun. Jurnal Kesehatan Masyarakat Nasional, 2015;9(3):249- 56.

20. Abuya AB, Ciera JK, Murage E. Effect of mother's education on child's nutritional status in the slums of Nairboi. BMC Pediatric. 2012;12:80-8.

21. Kuchenbecker J, Jordan I, Reinbott A, Herrmann J, Jeremias T, Kennedy G, et al. Exclusive breastfeeding and its effect on growth of Malawian infants : result from a cross-sectioanal study. Paediatr In Child Health. 2015;35(1):14-23.

22. Miranti P, Nanci M, Ratu AJM. Hubungan antara pemberian ASI eksklusif dengan kejadian stunting pada anak usia 13-36 bulan di wilayah kerja Puskesmas Tuminiting Kota Manado. Manado: Universtitas Sam Ratulangi; 2014. Artikel penelitian.

23. Astria PB, Hadi H, Gunawan A. Pemberian ASI eksklusif tidak berhubungan dengan stunting pada anak usia 6-23 bulan di Indonesia. Jurnal Gizi dan Dietetik Indonesia. 2015;3(3):162-71.

24. Milward D J. Nutrition, infection, and stunting : the roles of deficiencies of individual nutrients and food, and of inflammation, as determinans of reduced linear growth of children. Nutrition. 2017;30(1):50-72.

25. Agustrinognum. Hubungan karakteristik ibu dengan kejadian stunting pada balita usia 24-59 bulan di wilayah kerja Puskesmas Wonosari I. Artikel Penelitian. Yogyakarta: Universitas Aisyiyah; 2016. 